\title{
Triatoma juazeirensis sp. nov. from the state of Bahia, Northeastern Brazil (Hemiptera: Reduviidae: Triatominae)
}

\author{
Jane Costa ${ }^{+}$, Márcio Felix \\ Laboratório da Coleção Entomológica, Departamento de Entomologia, Instituto Oswaldo Cruz-Fiocruz, Av. Brasil 4365, 21045-900 \\ Rio de Janeiro, RJ, Brasil
}

Triatoma juazeirensis, a new triatomine species from the state of Bahia, Northeastern Brazil, is described. The new species is found among rocks in sylvatic environment and in the peridomicile. Type specimens were deposited in the Entomological Collection of Oswaldo Cruz Institute-Fiocruz, Museum of Zoology of University of São Paulo, and Florida Museum of Natural History. T. juazeirensis can be distinguished from the other members of the T. brasiliensis species complex mainly by the overall color of the pronotum, which is dark, and by the entirely dark femora.

Key words: Triatoma juazeirensis sp. nov. - Triatoma brasiliensis complex - Chagas disease vector - taxonomy - morphology Neotropics

The genus Triatoma Laporte, 1832 is currently known from 66 species of which 27 have been reported in Brazil (Galvão et al. 2003). Triatoma brasiliensis Neiva, 1911, the main Chagas disease vector in semiarid areas of Northeastern Brazil (Silveira \& Vinhaes 1999, Costa et al. 2003a), presents great chromatic variation. This aspect has lead in the past to the description of two melanic forms as subspecies: T. brasiliensis melanica Neiva \& Lent, 1941 and T. brasiliensis macromelasoma Galvão, 1956. A third chromatic form from the state of Bahia is also mentioned in Lent and Wygodzinsky (1979). These authors considered all of them as T. brasiliensis due to the allegation that intergrading forms are frequent in the natural environment.

Recently, multidisciplinary studies were carried out in order to clarify whether those melanic forms could represent different variations of T. brasiliensis or if they could be distinct evolutionary units. The results from approaches based on morphology (Costa 1997, Costa et al. 1997a), biology (Costa \& Marchon-Silva 1998), ecology (Costa et al. 1998, 2002), allozymes (Costa et al. 1997b), and mtDNA sequences (Monteiro et al. 2004) suggested that the distinct melanic forms (brasiliensis, melanica, macromelasoma, and juazeiro) are indeed independent evolutionary units constituting the $T$. brasiliensis species complex. A taxonomic review of this complex is in preparation.

In the present paper, a new species of the genus Triatoma from Bahia is described. The new species was considered by Lent and Wygodzinsky (1979) as one of the different melanic forms of $T$. brasiliensis and it refers to the darker form of the current $T$. brasiliensis species complex.

Financial support: CNPq, Funasa

${ }^{+}$Corresponding author: jcosta@ioc.fiocruz.br

Received 10 October 2006

Accepted 10 January 2007

\section{MATERIAL AND METHODS}

The material herein studied is deposited in the Coleção Entomológica, Instituto Oswaldo Cruz-Fiocruz, Rio de Janeiro, Brazil (CEIOC); Museu de Zoologia, Universidade de São Paulo, São Paulo, Brazil (MZUSP); and Florida Museum of Natural History (University of Florida), Gainesville, US (FLMNH). The description is according to the taxonomic characteristics for the Triatominae proposed by Galvão (1956) and Lent and Wygodzinsky (1979).

\section{DESCRIPTION}

Triatoma juazeirensis sp. nov. (Figure)

Length - Male 20-24 mm, female 23-25.5 mm; width of pronotum (posterior lobe): male 4.5-5.3 mm, female 4.4-5.5 mm; width of abdomen: male 6.9-8.8 $\mathrm{mm}$, female $8.3-10 \mathrm{~mm}$. All measurements are in the Table. Overall color black.

Head - Black, rugose dorsally and laterally. Head twice as long as wide across eyes (1:0.45-0.50) and distinctly longer than pronotum (1:0.65-0.85). Anteocular region four times as long as postocular (1:0.25), postocular region with sides slightly rounded. Clypeus distinctly but not abruptly widened behind middle. Genae tapering distally but their apex narrowly rounded, not pointed, slightly projecting beyond level of apex of clypeus. Jugae widely rounded apically. Eyes in lateral view approaching but not attaining level of under surface and remote from level of upper surface of head. Ratio width of eye to synthlipsis 1:1.75-2.00. Antenniferous tubercles inserted at or slightly before middle of anteocular region. First antennal segment attaining level of apex of clypeus; second segment subcylindrical, beset with declivous setae shorter than diameter of segment. Ratio of antennal segments 1:3.4-4.6:2.3-3.0:1.9-2.6. Rostrum thick, as dark as head capsule, with medium-sized hairs on first and on underside of second segment, and with long and very numerous hairs on upper surface of second and on 


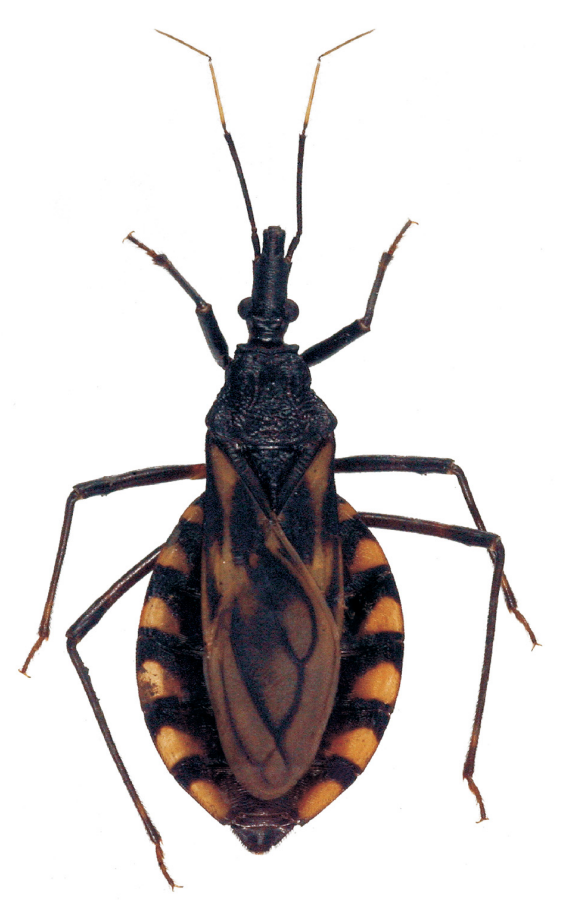

Triatoma juazeirensis sp. nov., dorsal habitus, female paratype.

entire third segment; hairs especially dense dorsally at junction of second and third segments. First rostral segment extending to level of apex of antenniferous tubercles, second to level of apex of middle of eyes. Ratio of rostral segments 1:1.6-2.2:0.8-1.2. Neck dark, with a pair of light-colored spots laterally.

Pronotum - with overall color dark; anterior lobe black, posterior lobe dark brown. Anterior lobe with very low discal tubercles; lateral tubercles absent. Posterior lobe coarsely rugose. Submedian carinae evanescent on pos- terior fourth of hind lobe. Humeral angles rounded, slightly angular.

Scutellum - Black, posterior process with small yellow or brownish yellow point on apex. Scutellum coarsely wrinkled, with or without a distinct central depression. Posterior process as long as main body of scutellum, subcylindrical, but slightly compressed laterally, apex slightly elevated, rounded.

Hemelytra - Extending to variable levels from base to apex of seventh urotergite. Corium light yellow, with dark areas of variable extension, mainly in lateral area limited by Sc, $\mathrm{R}+\mathrm{M}$ and free portion of $\mathrm{R}$, and on central area adjoining bases of membranal cells; areas mentioned joined in some specimens. Clavus entirely dark. Membrane fumose, yellowish brown, as light as light-colored areas of corium. Veins of membrane black; lumen of cells with more or less extensive, irregularly shaped sooty spot extending over central portion of cells.

Legs - Dark, with light markings on trochantera; femora entirely dark; subapical portion of tibiae slightly yellow. Legs slender, fore femora from six to seven times as long as wide. Fore and mid femora salient below subapically or with one or two weak denticles. Males with spongy fossulae on tibiae of fore and mid legs; absent in females.

Abdomen - Slightly flattened below in both sexes, delicately striate transversally, sparsely setose. Spiracles adjoining connexival suture. Abdomen of female very wide, lateral portions of urotergites exposed. Venter black; spiracles enclosed in minute yellow area. Connexival segments on disc with yellow rectangular or subtriangular yellow spot; wide black spot enclosing intersegmental sutures; yellow and black spots of about identical size, occupying entire width of segments.

Male genitalia. Structures as described by Lent and Jurberg (1978) to T. brasiliensis. [According to Costa

TABLE

Measurements (in mm) of Triatoma juazeirensis sp. nov.

\begin{tabular}{|c|c|c|c|c|c|c|c|c|c|c|}
\hline Gender & & & Male & & & & & Female & & \\
\hline Variables & Min. & Max. & $\mathrm{X}$ & $S^{2}$ & S & Min. & Max. & $\mathrm{X}$ & $S^{2}$ & $\mathrm{~S}$ \\
\hline Total length & 20.0 & 24.0 & 22.90 & 0.107 & 0.011 & 23.0 & 25.5 & 24.40 & 0.081 & 0.007 \\
\hline Length of head & 4.5 & 5.0 & 4.83 & 0.138 & 0.019 & 4.4 & 4.9 & 4.68 & 0.166 & 0.028 \\
\hline Width of head & 1.5 & 1.8 & 1.66 & 0.085 & 0.007 & 1.6 & 1.9 & 1.74 & 0.090 & 0.008 \\
\hline Synthlipsis & 1.0 & 1.2 & 1.08 & 0.072 & 0.005 & 1.1 & 1.3 & 1.16 & 0.064 & 0.004 \\
\hline Width of eyes & 0.5 & 0.7 & 0.55 & 0.059 & 0.004 & 0.5 & 0.6 & 0.55 & 0.045 & 0.002 \\
\hline Length of 1 st antennal segment & 0.9 & 1.1 & 0.98 & 0.073 & 0.005 & 0.8 & 1.1 & 0.95 & 0.090 & 0.008 \\
\hline Length of 2 nd antennal segment & 3.7 & 4.2 & 3.91 & 0.132 & 0.017 & 3.5 & 4.1 & 3.88 & 0.195 & 0.038 \\
\hline Length of 3rd antennal segment & 2.5 & 2.9 & 2.58 & 0.116 & 0.013 & 2.3 & 2.8 & 2.55 & 0.165 & 0.027 \\
\hline Length of 4 th antennal segment & 2.0 & 2.3 & 2.26 & 0.104 & 0.011 & 2.1 & 2.4 & 2.30 & 0.122 & 0.015 \\
\hline Length of 1 st rostral segment & 1.1 & 1.5 & 1.22 & 0.117 & 0.014 & 1.1 & 1.3 & 1.16 & 0.067 & 0.004 \\
\hline Length of 2 nd rostral segment & 2.0 & 2.5 & 2.30 & 0.131 & 0.017 & 2.2 & 2.4 & 2.32 & 0.094 & 0.009 \\
\hline Length of 3rd rostral segment & 1.1 & 1.3 & 1.20 & 0.047 & 0.002 & 1.2 & 1.4 & 1.27 & 0.065 & 0.004 \\
\hline Length of pronotum & 3.1 & 4.0 & 3.66 & 0.273 & 0.074 & 3.3 & 3.9 & 3.65 & 0.195 & 0.038 \\
\hline Anterior width of pronotum & 2.1 & 2.5 & 2.27 & 0.107 & 0.011 & 2.2 & 2.6 & 2.32 & 0.125 & 0.016 \\
\hline Posterior width of pronotum & 4.5 & 5.3 & 4.91 & 0.240 & 0.057 & 4.4 & 5.5 & 4.98 & 0.367 & 0.135 \\
\hline Width of abdomen & 6.9 & 8.8 & 7.93 & 0.645 & 0.416 & 8.3 & 10.0 & 8.80 & 0.452 & 0.205 \\
\hline
\end{tabular}


et al. (1997a) the variations on male genital structures of $T$. brasiliensis are not correlated with its different chromatic forms. Therefore, these structures are not useful to distinguish the new species.].

Etymology - The specific epithet, juazeirensis, refers to the municipality of Juazeiro (Bahia) in which the type material of the new species was collected.

Type material - Female holotype and 17 paratypes ( 5 males and 12 females), Juazeiro (9 $24^{\circ} 42^{\prime \prime} \mathrm{S}$, $\left.40^{\circ} 29^{\prime} 55^{\prime \prime} \mathrm{W}\right)$, Bahia, Brazil (CEIOC). Four paratypes (2 males and 2 females), same locality (MZUSP). Four paratypes (2 males and 2 females), same locality (FLMNH).

Diagnosis - T. juazeirensis can be distinguished from the other members of the T. brasiliensis species complex mainly by the overall color of pronotum, which is dark, and by the entirely dark femora.

\section{DISCUSSION}

Several field captures were carried out throughout the geographic distribution of the $T$. brasiliensis species complex from 1994 to 2002. A total of 2010 specimens were compared according to their chromatic patterns and geographic distribution. Adult specimens of $T$. brasiliensis (113) from Herman Lent Collection and one type specimen from Cesar Pinto Collection (Instituto Oswaldo Cruz) were also observed. The color pattern of T. juazeirensis was found only in the state of Bahia, while intermediate forms were not found in this state (Costa 1997). Furthermore, several colonies reared under laboratory conditions for more than ten years showed that $T$. juazeirensis color pattern is stable, homogeneous, and can be easily distinguished from the other patterns observed in the brasiliensis complex (Costa 1997, Costa et al. 1997a). This chromatic pattern is associated to ecologic and molecular characteristics (Costa et al. 2002, Monteiro et al. 2004). For instance, the ecologic niche modeling showed that the color patterns of the brasiliensis complex are not influenced by environmental differences across its distribution, and the levels of genetic divergence are comparable to those of other closely related triatomine species. The congruence of these results, which were obtained from the analysis of different data, strongly suggests that $T$. juazeirensis is a distinct species.

Despite the morphologic, ecologic, and genetic distances registered for the members of the brasiliensis complex, viable offsprings are produced in crossing experiments under laboratory conditions, suggesting a monophyletic origin for the group (Costa et al. 2003b). On the other hand, the molecular approaches show that T. juazeirensis is reproductively isolated from the other species of the complex in natural environments, confirming that it is indeed an independent evolutionary unit (Costa et al. 1997b, Monteiro et al. 2004).

The epidemiological importance of each species of the brasiliensis complex is very distinct and therefore the definition of the taxonomic status of its members is highly important in order to better address epidemio- logical studies and control measures. T. juazeirensis can be found in the sylvatic environment, among rocks, in similar ecotopes as those ones infested by $T$. brasiliensis (Alencar 1987, Costa et al. 1998) and it is mostly found in peridomiciles. However, it also plays an important role in the domiciliary infestation (Costa et al. 2003a) and therefore it should be kept under surveillance, according to data based on captures carried by National Health Foundation - Brazil (Funasa).

\section{ACKNOWLEDGEMENTS}

To Archibaldo Belo Galvão (in memorium) and Herman Lent (in memorium) for important suggestions and incentive. To Maria Goreti Rosa Freitas and Carlos Eduardo Almeida for critic reviews. To the technicians of National Health Foundation in Brazil for the valuable help during the field captures. To Dr Italo Sherlock for suggesting the specific epithet.

\section{REFERENCES}

Alencar JE 1987. História Natural da Doença de Chagas no Estado do Ceará, Imprensa Universitária, UFC, Fortaleza, $341 \mathrm{pp}$.

Costa J 1997. Triatoma brasiliensis Neiva, 1911 (Hemiptera, Reduviidae, Triatominae): Estudos Morfológicos, Biológicos e Isoenzimáticos sobre Diferentes Padrões Cromáticos, PhD Thesis, Instituto Oswaldo Cruz-Fiocruz, Rio de Janeiro, $100 \mathrm{pp}$.

Costa J, Marchon-Silva V 1998. Período de intermuda e resistência ao jejum de diferentes populações de Triatoma brasiliensis (Hemiptera, Reduviidae, Triatominae). Entomol Vec 5: 2334.

Costa J, Almeida CE, Dotson EM, Lins A, Vinhaes M, Silveira AC, Beard CB 2003a. The epidemiologic importance of Triatoma brasiliensis as a Chagas disease vector in Brazil: a revision of domiciliary captures during 1993-1999. Mem Inst Oswaldo Cruz 98: 443-449.

Costa J, Almeida CE, Dujardin JP, Beard CB 2003b. Crossing experiments detect genetic incompatibility among populations of Triatoma brasiliensis Neiva, 1911 (Heteroptera, Reduviidae, Triatominae). Mem Inst Oswaldo Cruz 98: 637-639.

Costa J, Almeida JR, Britto C, Duarte R, Marchon-Silva V, Pacheco R 1998. Ecotopes, natural infection and trophic resources of Triatoma brasiliensis (Hemiptera, Reduviidae, Triatominae). Mem Inst Oswaldo Cruz 93: 7-13.

Costa J, Barth OM, Marchon-Silva V, Almeida CE, Freitas-Sibajev MG, Panzera F 1997a. Morphological studies on the Triatoma brasiliensis Neiva, 1911 (Hemiptera, Reduviidae, Triatominae) - Genital structures and eggs of different chromatic forms. Mem Inst Oswaldo Cruz 92: 493-498.

Costa J, Freitas-Sibajev MG, Marchon-Silva V, Pires MQ, Pacheco $\mathrm{R} 1997 \mathrm{~b}$. Isoenzymes detect variation in populations of Triatoma brasiliensis (Hemiptera-Reduviidae-Triatominae). Mem Inst Oswaldo Cruz 92: 459-464.

Costa J, Peterson AT, Beard CB 2002. Ecologic niche modeling and differentiation of populations of Triatoma brasiliensis Neiva, 1911, the most important Chagas' disease vector in northeastern Brazil (Hemiptera, Reduviidae, Triatominae). Am J Trop Med Hyg 67: 516-520.

Galvão AB 1956. Triatoma brasiliensis macromelasoma $\mathrm{n}$. subsp. (Reduviidae, Hemiptera). Rev Bras Malariol Doen Trop 7: 455-457. 
Galvão C, Carcavallo R, Rocha DS, Jurberg J 2003. A checklist of the current valid species of the subfamily Triatominae Jeannel, 1919 (Hemiptera, Reduviidae) and their geographical distribution, with nomenclatural and taxonomic notes. Zootaxa 202: 1-36.

Lent H, Jurberg J 1978. Estudo comparativo da genitália externa masculina de seis espécies de Triatoma Laporte, 1832 que mais freqüentemente habitam o domicílio humano no Brasil (Hemiptera, Reduviidae). Rev Bras Biol 38: 931-944.
Lent H, Wygodzinsky P 1979. Revision of the Triatominae (Hemiptera, Reduviidae) and their significance as vectors of Chagas' disease. Bull Am Mus Nat Hist 163: 125-520.

Monteiro FA, Donnelly MJ, Beard CB, Costa J 2004. Nested clade and phylogeographic analyses of the Chagas disease vector Triatoma brasiliensis in Northeast Brazil. Mol Phylogenet Evol 32: 46-56.

Silveira AC, Vinhaes MC 1999. Elimination of vector-borne transmission of Chagas disease. Mem Inst Oswaldo Cruz 94 (Suppl. I): 405-411. 